\title{
Upward Revaluation of Fixed Assets
}

\author{
Zhemin Wang, (E-Mail:wangz@uwp.edu), University of Wisconsin-Parkside
}

\begin{abstract}
Under the U.S. GAAP, fixed assets are reported at their book values which are derived by deducting accumulated depreciation from the original cost. Companies are allowed to write down their fixed assets if the value of the fixed assets is impaired. Under no circumstances can a company write up its fixed assets even if the market value of these assets exceeds their book value. However, such upward revaluation is allowed under the International Accounting Standards (IAS). Specifically, as an allowed alternative, IAS No.16, "Property, Plant \& Equipment," permits fixed assets to be revalued periodically and carried at fair value. Significant controversies currently exist regarding the revaluation provision under IAS No.16. Critics of IAS No.16 have expressed concerns that revaluation of fixed assets is arbitrary and may be used by management to manipulate reported accounting numbers. To address such concerns, this study empirically assesses the reported fixed assets under IAS No.16. Based on the data of 113 companies whose consolidated financial statements were prepared using IAS, this study documented significant empirical evidence suggesting that fixed assets reported by sample firms under IAS No. 16 reflect their economic value as perceived by investors. The findings seem to support the use of IAS in preparation of financial statements for cross-border listing of securities.
\end{abstract}

\section{INTRODUCTION}

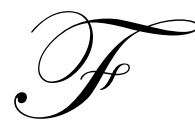

or over 30 years, the International Accounting Standards Board (IASB) and its predecessor, the International Accounting Standards Committee (IASC) have been working to develop a single set of accounting standards which can be used by businesses and other organizations for financial reporting around the world. With a remarkably broad base of support, IASB has become the driving force in international accounting standards setting. Now the IASB represents more than 120 accounting organizations from over 90 countries. Over 50 countries have adopted IAS as their national standards. Furthermore, the International Organization of Securities Commissions has recommended that the world's securities regulators permit foreign issuers to use IAS in preparing financial statements for cross-border offerings and listings. Stock exchanges in London, Frankfurt, Zurich, Luxemburg, Hong Kong, Amsterdam, and Rome, among others, now accept financial statements prepared using IAS (Ashbaugh and Olson, 2002). Starting in 2005, the European Union requires companies in all of its member countries and the three European Economic Area states to use IAS in preparing consolidated financial statements (Eichhorst et. al., 2002).

Despite the wide acceptance of IAS-based financial statements, questions regarding the quality of IAS remain the major obstacle to IAS' universal acceptance for cross-border listing of securities. This study addresses the issue of IAS quality by empirically examining the quality of reported fixed assets under IAS No.16 "Property, Plant, and Equipment." IAS No.16 is chosen for two major reasons: (1) fixed assets are a principal component of most corporate balance sheets; and (2) significant controversies exist regarding the revaluation (particularly the upward revaluation) provision of IAS No.16 (Sonnelitter, 1999).

Allowing upward revaluation of fixed assets has been one of the most controversial policy issues facing standard setting bodies across the world. The issuance of IAS No.16 permitting upward revaluation of fixed assets has not put this controversy to rest. Significant controversies continue to exist regarding the appropriate accounting treatment for fixed assets and the use of fair value accounting. Instead of making another argument for or against the IASB's fixed assets accounting standards, this study takes a different approach. That is, it simply attempts to document empirical evidence regarding investors' assessment of reported fixed assets by companies whose financial statements are prepared using IAS. Specifically, this study uses a cross-sectional equity valuation model introduced by Landsman (1986) and subsequently used in numerous research studies (Jennings et al., 1996; Duvall et al., 1992; and Wang, 1993). The magnitude of the coefficient estimate for fixed assets from the equity model regression is compared to its theoretical value. A fixed asset coefficient close to its 
theoretical value would indicate that reported fixed asset is viewed by investors as reflecting its economic value, and, therefore, can be interpreted as positive evidence for the use of IAS in preparation of financial statements for cross-border listings. On the other hand, a fixed asset coefficient that is significantly less than its theoretical value would indicate that reported fixed asset is overstated and can be interpreted as negative evidence against IASB's fixed asset accounting standards. Given accounting profession's longstanding convention of conservatism, an overstatement of fixed assets would be of great concern to standards setting bodies.

A number of multinational companies have been preparing consolidated financial statements using IAS. This study collected fixed assets and other financial data for 1999 from 113 companies representing eight countries/regions. All sample companies prepared their consolidated financial statements using IAS. Empirical evidence from the sample companies indicates that the coefficient estimate for fixed assets is very close to its theoretical value. This evidence is consistent with the claim that IAS No.16 is of high quality and can be rigorously interpreted and applied.

The findings have direct policy implications in that it justifies the widespread acceptance of IASB's reporting standards by its member countries and stock exchanges. The results, however, must be interpreted with caution for two reasons. First, due to the lack of data availability, the sample used in this study consists of only 113 companies for the year of 1999. The second limitation of this study is its sample composition. Because of concerns over auditing quality and capital market efficiency, companies from developing countries were not included. The final sample consists of mostly large multinational corporations from eight industrialized countries/regions. Future studies may want to find ways to include more companies with varying sizes and stages of economic development. Such studies can provide further insight on the issue of whether IAS can be interpreted and applied equally rigorously by companies of all sizes and from countries in different stages of economic development.

The rest of the study is organized as follows. Section 2 discusses issues related to fixed asset accounting controversy and develops the model. Section 3 describes sample selection and the data. Section 4 presents empirical tests and results. The last section summarizes and concludes the paper.

\section{FIXED ASSET ACCOUNTING CONTROVERSY AND MODEL DEVELOPMENT}

Upward revaluation of fixed assets has been one of the most controversial policy issues facing accounting standard setting bodies across the world. Some argue that the fair value of fixed assets is more relevant for making economic decisions and, therefore, should be used for reporting fixed assets. Many standardsetting bodies and practitioners, however, argue that such upward revaluation is arbitrary and unreliable. Furthermore, it gives management an opportunity to manipulate the reported accounting numbers. It is argued that such practice would shake investors' confidence in financial reporting in general, and thus should not be allowed.

After several years of elaboration, IASC (IASB's predecessor) issued IAS No.16, "Property, plant, and equipment," in 1998. IAS No.16 permits fair value accounting for fixed assets under its allowed alternative treatment. In a number of countries including the United States, however, fair value accounting is not permitted for the reporting of fixed assets.

IASB's new fixed asset policy has not put the revaluation controversy to rest. Instead, it has stirred up new debate on whether the standard enhanced reporting quality (Sonnelitter, 1999; Bean and Jarnagin, 2001). Critics of IAS No.16 argue that allowing the use of fair value accounting for fixed assets under IAS No.16 reduces the comparability of reported fixed assets across different companies. Others point out the necessary arbitrariness in revaluing fixed assets subsequent to acquisition, which provides further opportunities for management manipulation of reported accounting numbers (Bloomer, 1999). Proponents of IAS No.16 argue that fair value information is more relevant for decision making than depreciated cost (book value), and therefore, should be allowed (Davis and Davis, 1996; Skinner, 1988; Means and Kazenski, 1988; King, 1994; Woolridge, 1988). Instead of making another argument for or against IAS No.16, this study adopts a different approach in addressing the fixed assets accounting controversy. That is, this study attempts to document some empirical evidence regarding investors' assessment of reported fixed assets under IAS No.16. Specifically, it uses an equity valuation model by Landsman (1986) which holds that shareholders' equity is the residual of corporate assets less corporate liabilities. The market valuation of reported fixed assets under IAS No.16 will be compared to its theoretical 
value. If we let FA, MVNFA, and MVL represent the firm's fixed assets, the market value of non-fixed assets, and total liabilities respectively, the market value of the shareholders' equity, MVE is given by:

MVE $=\beta_{1} \mathrm{MVNFA}+\beta_{2} \mathrm{FA}+\beta_{3} \mathrm{MVL}$

Market value of shareholders' equity is computed based on price per share and the number of shares outstanding. Analogous to Landsman's approach (1986), book values of non-fixed assets and total liabilities are used in the empirical test of this study. Consequently, the empirical analogue of the theoretical model given by Equation 1 is:

$\mathrm{MVE}_{\mathrm{i}}=\mathrm{b}_{0}+\mathrm{b}_{1} \mathrm{NFA}_{\mathrm{i}}+\mathrm{b}_{2} \mathrm{FA}_{\mathrm{i}}+\mathrm{b}_{3} \mathrm{TL}_{\mathrm{i}}+\mathrm{e}_{\mathrm{i}}$

where NFA and TL represent the book value of non-fixed assets and total liabilities, respectively. The theoretical values of the coefficient estimates for NFA and TL, $b_{1}$ and $b_{3}$, are +1 and -1 , respectively (see Landsman, 1986). The focus of the empirical test of this study is on the magnitude of the coefficient estimate for fixed assets, $b_{2}$. If the reported fixed assets under IAS No.16 reflect their economic value as perceived by investors, the coefficient estimate for fixed assets, $b_{2}$ should be close to its theoretical value of +1 . Such evidence would support the claim that IASB's fixed asset accounting standards are of high quality. This would also be supportive of the widespread acceptance of IAS-based financial statements by major stock exchanges. On the other hand, if investors are concerned with potential management manipulation in applying the fair value accounting in reporting fixed assets under IAS No.16, the coefficient estimate for fixed assets would not be significantly different from zero. A coefficient estimate that is greater than zero, but significantly less than its theoretical value of +1 implies that reported fixed assets are overstated. Given the profession's longstanding convention of conservatism, such evidence would be of great concern to standard setting bodies.

\section{SAMPLE SELECTION AND THE DATA}

As IAS are accepted by more and more stock exchanges, the number of companies preparing IAS based annual reports has increased steadily during the last decade. Furthermore, in some countries (such as France and Germany, among others), national standards govern only the preparation of parent companies' annual report. In these countries, some multinational companies have been preparing their consolidated financial statements using IAS. In order to test investors' perception of reported fixed assets under IAS No.16, companies preparing IASbased consolidated financial statements were identified and financial and pricing data of these companies were collected. Specifically, a list of about 900 companies preparing IAS-based financial statements was first obtained from IASB's web site (www.iasb.org.uk). Since reporting quality is a function of both standards quality and auditing quality, low auditing quality may result in lower reporting quality even if the standard quality is high. Given the concern over auditing quality in developing countries (Choi and Meek, 2005), 444 companies from less developed countries were excluded to eliminate the potential compounding factor of auditing quality. The second reason companies from less developed countries were not included in the sample is the lack of empirical evidence regarding the capital market efficiency in these countries whereas capital market efficiency is an important assumption of the equity model regression.

To obtain financial information for the remaining companies on the list, the companies' websites were searched first. If the required information is not available on the websites, attempts then were made to obtain hard copies of IAS-based annual reports directly from the companies. This effort resulted in 113 IAS-based annual reports from eight countries/regions (see Table 1).

Table 1 Sample Composition

\begin{tabular}{|c|c|c|c|}
\hline Country & No. of Companies & Country/region & No. of Companies \\
\hline Canada & 8 & Hong Kong (region) & 7 \\
\hline Finland & 5 & Japan & 16 \\
\hline France & 21 & Sweden & 33 \\
\hline Germany & 19 & Switzerland & 113 \\
\hline Total
\end{tabular}




\section{EMPIRICAL TESTS AND RESULTS}

Equation 2 is used to assess the market valuation of reported fixed assets for sample companies. Consistent with the discussion in Section 2, a fixed asset coefficient that is substantially equal to its theoretical value of +1 would indicate that the reported fixed assets under IAS No.16 reflect the economic value of the underlying assets as perceived by investors, and, therefore, would support the view that IAS No.16 is of high quality. However, a fixed asset coefficient that is significantly less than its theoretical value of +1 would indicate that reported fixed assets are significantly overstated as perceived by investors. Given the profession's longstanding convention of conservatism, this should be of particular concern to the IASB and standard setting bodies across the world.

Before regressing the market value of equity on the book value of assets and liabilities, the data are transformed by deflating all regression variables using net sales to mitigate the heteroscedasticity problem (Park, 1966). Specifically, Equation 2 was first estimated using untransformed data to obtain the residuals, $e_{i}$. Then the relationship between the residuals and sales is estimated using the following equation:

$\operatorname{Ln}\left(\mathrm{e}_{\mathrm{i}}\right)=\Gamma_{0}+\Gamma_{1} \mathrm{SALES}_{\mathrm{i}}+\Gamma_{2}\left(\mathrm{SALES}_{\mathrm{i}}\right)^{2}+\mathrm{v}_{\mathrm{i}}$

The estimated values of $\Gamma$ s are then used to transform the regression variables by deflating each variable by the following expression:

$\operatorname{SALES}\left(\Gamma_{1}+\Gamma_{2} \operatorname{Ln}(\right.$ sales $\left.)\right) / 2$

Sample descriptive statistics of all regression variables both before and after data transformation are presented in Table 2 .

Table 2: Sample Descriptive Statistics

\begin{tabular}{|l|r|r|r|r|}
\hline \multicolumn{1}{|c|}{ Variables } & Mean & Std. Dev. & Mean & Std. Dev. \\
\hline \multicolumn{2}{|c|}{ Untransformed } & \multicolumn{2}{c|}{ Transformed } \\
\hline NFA & 18,733 & 29,347 & 7,388 & 13,043 \\
\hline FA & 1,758 & 2,594 & 1,169 & 1,423 \\
\hline TL & 10,918 & 27,954 & 5,413 & 10,415 \\
\hline MVE & 5,278 & 9,463 & 3,154 & 6,830 \\
\hline
\end{tabular}

NFA: Book value of total non-fixed assets.

TL: Book value of total liabilities.

FA: Book value of fixed assets.

MVE: Market value of shareholders' equity.

The regression results of Equation 2 using the transformed data are presented in Table 3. All coefficient estimates have the predicted signs. The three independent variables explained 78 percent of the cross-sectional variations in the market value of sample firms' equities. More important, the fixed asset coefficient, $b_{2}$ is 1.33 , and is not statistically different from its theoretical value of $+1(t=0.77)$. The null hypothesis that $b_{2}$ is zero was rejected at .01 significance level $(\mathrm{t}=3.12)$. The result suggests that the reported fixed assets under IAS No.16 reflect the economic value of the underlying assets as perceived by investors. The findings are consistent with the view that IAS No.16's fixed asset provisions are of high quality.

While the results presented in Table 3 support IAS No.16's fixed asset provisions, there is a legitimate concern over the test results. That is, the variance inflation factors (VIF) for total non-fixed assets and total liabilities were high, indicating the existence of a multicollinearity problem. When a multicollinearity problem exists, the ordinary least squares (OLS) estimates tend to be unstable and inflated (Cryer and Miller, 1994). One approach frequently used in the literature to mitigate the problem of multicollinearity is to discard some of the highly correlated independent variables. Since the regression model in this study was based on the accounting identity, a logical choice would be to use net asset which is the net of total non-fixed assets and total liabilities to replace these two highly correlated independent variables. Specifically, the following net asset model was estimated: 
Table 3: Regression Summary Statistics

Model: $\mathrm{MVE}_{\mathrm{i}}=\mathrm{b}_{0}+\mathrm{b}_{1} \mathrm{NFA}_{\mathrm{i}}+\mathrm{b}_{2} \mathrm{FA}_{\mathrm{i}}+\mathrm{b}_{3} \mathrm{TL}_{\mathrm{i}}+\mathrm{e}_{\mathrm{i}}$ $\mathrm{n}=113$

\begin{tabular}{|l|c|c|c|c|c|}
\hline & $\mathbf{b}_{\mathbf{0}}$ & $\mathbf{b}_{\mathbf{1}}$ & $\mathbf{b}_{\mathbf{2}}$ & $\mathbf{b}_{\mathbf{3}}$ & Adj. $^{\mathbf{2}}$ \\
\hline & & & & & \\
\hline Estimate & 516.03 & 1.12 & 1.33 & -1.09 & .78 \\
\hline t-ratio & 1.47 & 5.65 & 3.12 & -4.37 & \\
\hline Prob>|t| & .10 & .01 & .01 & .01 & \\
\hline
\end{tabular}

MVE: Market value of shareholders' equity

NFA: Book value of total non-fixed assets

TL: Book value of total liabilities

FA: Book value of fixed assets

The regression results using the net asset model are presented in Table 4. The regression coefficient for fixed assets is consistent with that obtained from the balance sheet model in Table 3. Specifically, the fixed asset coefficient is 1.40 and is not statistically different from its theoretical value. The null hypothesis that the coefficient estimate for fixed assets under IAS No.16 is zero was rejected at .01 significance level $(\mathrm{t}=3.21)$. Furthermore, similar result was also obtained for the coefficient estimate for net assets. The regression coefficient for net assets is 1.13 . This value is also significantly different from zero and is not significantly different from its theoretical value of +1 .

Table 4: Regression Summary Statistics

Model: $\mathrm{MVE}_{\mathrm{i}}=\mathrm{b}_{0}+\mathrm{b}_{1} \mathrm{NA}_{\mathrm{i}}+\mathrm{b}_{2} \mathrm{FA}_{\mathrm{i}}+\mathrm{e}_{\mathrm{i}}$ $\mathrm{n}=113$

\begin{tabular}{|l|c|c|c|c|}
\hline & $\mathbf{b}_{\mathbf{0}}$ & $\mathbf{b}_{\mathbf{1}}$ & $\mathbf{b}_{\mathbf{2}}$ & Adj. $^{\mathbf{2}}$ \\
\hline & & & & \\
\hline Estimate & 533.12 & 1.13 & 1.40 & .78 \\
\hline t-ratio & 1.81 & 5.37 & 3.21 & \\
\hline Prob>|t| & .10 & .01 & .01 & \\
\hline
\end{tabular}

MVE: Market value of shareholders' equity

NA: Book value of total net assets excluding fixed assets

FA: Book value of fixed assets

In summary, the evidence in Tables 3 and 4 cannot reject the hypothesis that the fixed asset coefficient is equal to its theoretical value of +1 , implying that reported fixed assets by the 113 sample companies from eight countries/regions reflect the economic value of the underlying fixed assets as perceived by investors. The evidence seems consistent with the view that IAS No.16's fixed asset provisions are of high quality and can be rigorously interpreted and applied at least by the sample companies. It has direct policy implications in that it justifies the widespread acceptance of IAS-based financial statements by many stock exchanges.

\section{CONCLUDING REMARKS}

International accounting standards have been gaining increasing acceptance from standards setting bodies and stock exchanges across the world since mid1990s. However, questions regarding the quality of IASB standards remain the major obstacle to IAS' universal acceptance. This study attempted to document empirical evidence regarding investors' perception of reported fixed assets under IAS No.16. Using data from 113 companies whose financial statements were prepared using IAS, significant evidence was obtained suggesting that the reported fixed asset by sample firms reflects its economic value as perceived by investors. The coefficient estimate for fixed assets from the equity model regression was not significantly different from its theoretical value of +1 , suggesting that allowing fair value revaluation of fixed assets was not a serious concern to investors. This evidence seems to justify the widespread acceptance of IAS for cross-border listings of securities. 
The empirical results should be interpreted with caution because of two limitations of this study. The first limitation is its small sample size. Because of the lack of data availability, the test results of this study were based on a sample of only 113 companies for the year of 1999. The second limitation of this study is its sample composition. Because of concerns about auditing quality and capital market efficiency, companies from developing countries were excluded and, consequently, the final sample is made up of mostly large multinational companies from eight industrialized countries/regions. In light of the positive relationship between multinationality and reporting quality documented in the existing literature, this study's findings, which are based on data from large multinational companies, may not be readily generalizable to all companies. In order to determine the generalizability of the findings, future research studies should employ more creative research designs to include more companies with varying sizes and from countries with varying stages of economic development. Such studies would provide further insight on investors' assessment of IAS quality.

\section{REFERENCES}

1. Ashbaugh, H., and P. Olson, An Exploratory Study of the Valuation Properties of Cross-listed Firms' IAS and U.S. GAAP Earnings and Book Values, The Accounting Review, Vol. 77, pp.107-126, 2002.

2. Bean, L. and B. Jarnagin, Intangible Asset Accounting: How do Worldwide Rules Differ? Journal of Corporate Accounting and Finance, pp. 55-65, November/December 2001.

3. Bloomer, C., The IASC-US Comparison Project: A Report on the Similarities and Differences between IASC Standards and U.S. GAAP, Financial Accounting Standards Board, 1999.

4. Choi, F. and Gary Meek, International Accounting, Prentice Hall, 2005.

5. Cryer, J. and R. Miller, Statistics for Business: Data Analysis and Modeling, 1994.

6. Davies, Michael and Paul Davies, An Impairment Measure That's Seriously Impaired, Accountancy, pp.77, October, 1996.

7. Duvall, L., Jennings R., Robinson, J., and R. Thompson, Can Investors Unravel the Effects of Goodwill Accounting? Accounting Horizons, pp.14, June, 1992.

8. Eichhorst, R., Steen B., Van Der Tas, L., and M. Smits, IAS 2005: Preparing Your Enterprise for New International Financial Reporting Standards, Harperion, 2002.

9. International Accounting Standard No.16, Property, Plant, and Equipment, International Accounting Standards Board, London, England, 1998.

10. Jennings, R., Simko, P., and R. Thompson, Does LIFO Inventory Accounting Improve Income Statement at the Expense of Balance Sheet? Journal of Accounting Research, Volume 34, pp.85-109 Spring 1996.

11. King, Alfred M., Asset Impairment: Is Current Value Accounting Sneaking in the Back Door? Management Accounting, pp. 36-40, March, 1994.

12. Landsman, J., An Empirical Investigation of Pension Fund Property Rights, Accounting Review, pp.662691, October 1986.

13. Means, K.M. and P.M. Kazenski, SFAS No.34: A Recipe for Diversity, Accounting Horizons, pp.62-67, September, 1988.

14. Park, R., Estimation with Heteroscedastic Error Terms, Econometrica, p.888, October, 1966.

15. Skinner, R.C., Role of Conservatism in Determining the Accounting Lives of Fixed Assets, International Journal of Accounting Education and Research, pp.1-18, Spring, 1988.

16. Sonnelitter, Jr. R., Comparative Analysis of IAS 16 "Property, Plant and Equipment" and Related U.S. GAAP, The IASC-U.S. Comparison Project, pp.175-188, 1999,.

17. Wang, Z., An Empirical Evaluation of Goodwill Accounting, The Journal of Applied Business Research, Vol.9, No.4, pp.127-133, 1993.

18. Woolridge, R., Competitive Decline and Corporate Restructuring: Is a Myopic Stock Market to Blame? Journal of Applied Corporate Finance, pp.26-36, 1988. 